\title{
Formulation and evaluation of transdermal drug-delivery system of isosorbide dinitrate
}

\author{
Xiaoping Zhan1, Zhenmin Mao, ${ }^{1, *}$,Sijing Chen', Shaoxiong Chen², Liqun Wang² \\ ${ }^{1}$ School of Pharmacy, Shanghai Jiaotong University, Shanghai, P R China, ${ }^{2}$ Strategic Alliance of Biomedical Technology, \\ Shanghai, P R China
}

\begin{abstract}
The purpose of this study was to develop a reservoir-type transdermal delivery system for isosorbide dinitrate (ISDN). The developed patch consisted of five layers from bottom to top, namely, a temporary liner, an adhesive layer, a rate-controlling membrane, a reservoir and a backing. The effects of chemical penetration enhancers, reservoir materials and rate-controlling membranes on the release behaviour of ISDN from the transdermal patch were studied, and the in vitro release of ISDN from the developed patch was studied and compared with the commercially available ISDN patch. The results showed that there was no significant difference in permeation rates between the developed reservoir-type patch and the commercially available ISDN patch $(p>0.05)$. Moreover, the cumulative release ratio of the commercially available ISDN patch in $48 \mathrm{~h}$ was up to $89.8 \%$, whereas the developed patch was only $34.9 \%$, which meant the sustained release time of the developed patch was much longer than the commercially available ISDN patch, and would promote the satisfaction of the patient.
\end{abstract}

Uniterms: Isosorbide dinitrate/transdermal drug-delivery system. Transdermal patches/in vitro release. Transdermal patches/sustained release. Controlling membrane/drugs release rate. Skin penetration/ drugs release.

O objetivo do presente estudo foi desenvolver um sistema de liberação transdérmico do tipo reservatório para o dinitrato de isossorbida (ISDN, abrevitura em Inglês). A formulação transdérmica desenvolvida constou de cinco camadas de baixo para cima, ou seja, um revestimento temporário, uma camada adesiva, uma membrana controladora da taxa de liberação, um reservatório e um reforço. Estudaram-se os efeitos dos potenciadores de penetração química, materiais do reservatório e membranas de controle da taxa de liberação no comportamento da formulação transdérmica de dinitrato de isossorbida. A liberação in vitro da formulação transdérmica de dinitrato de isossorbida desenvolvida foi estudada em comparação com a formulação de dinitrato de isossorbida disponível comercialmente. Os resultados mostraram que não existem diferenças significativa nas taxas de permeação entre o tipo de reservatório desenvolvido e o de dinitrato de isossorbida desenvolvido comercialmente $(p>0,05)$. Ademais, a taxa de liberação cumulativa da formulação de dinitrato de isossorbida disponível comercialmente em 48 horas foi de até $89,8 \%$ e a da formulação desenvolvida, de apenas de $34,9 \%$, o que provou que a liberação sustentada da formulação desenvolvida foi muito maior do que a de dinitrato de isossorbida desenvolvida comercialmente, o que promoveria a satisfação do paciente.

Unitermos: Dinitrato de isossorbida/Sistema de liberação transdérmico. Formulações transdérmicas/ liberação in vitro. Formulações transdérmicas/liberação sustentada. Membrana de controle/taxa de liberação de fármacos. Penetração cutânea/liberação de fármacos.

*Correspondence: Zhenmin Mao. School of Pharmacy. Shanghai Jiaotong

University. Shanghai 200240, P. R. China. E-mail: zmmao@sjtu.edu.cn 


\section{INTRODUCTION}

Transdermal-patch technology has advanced tremendously since the first scopolamine patch was introduced into the market in 1979. It can be attributed to today's advanced patch-making technology, through which nearly a billion patches are manufactured every year (Prausnitz, Langer, 2008). These transdermal patches are classified into three types: drug in adhesive (the drug is directly dispersed into the adhesive polymer), reservoir (consists of a drug reservoir between a backing membrane and rate-controlling membrane, with a skin-contacting adhesive layer) and matrix (consists of a drug reservoir in the centre with a peripheral adhesive ring around the edges) (Tan, Pfister, 1999; Subedi et al., 2010).

Isosorbide dinitrate (ISDN) is commonly used for the therapy of stable angina pectoris and is traditionally administrated via oral or sublingual routes. However, loss of consciousness appears in patients when angina pectoris breaks out, and thus it is difficult for patients to take the medicine by themselves. Additionally, administrated orally ISDN has low bioavailability, owing to its high first-pass metabolism in the gastrointestinal tract and liver. Moreover, the critical point of anti-anginal therapy depends, to a certain extent, on the ability of the drug to produce an immediate effect (Johnson, Gladigau, Schnelle, 1981; Fung, 1985; Taylor et al., 1985). Thus, transdermal delivery may be an appropriate administration route for ISDN.

Among the ISDN transdermal patches designed and reported previously, the drug-in-adhesive patches are the simplest and the most commonly used design. Zhao et al. (2007) developed single-layer drug-in-adhesive transdermal patches, in which the adhesive layer not only serves as an adhesion layer to the skin, but also is responsible for the release of the drug. The in vitro release results show that the release kinetics of ISDN is a first-order process, suggesting that the outwards moving of ISDN from the adhesive is associated with a passive diffusion process.

Drug release from a drug-in-adhesive patch depends directly upon the drug concentration in the patch and follows first-order kinetics. However, reservoir-type transdermal drug delivery could be observed the zeroorder kinetics. The rate controlling membrane, as a most important component in the reservoir-type transdermal patch, was responsible for controlling drug delivery. The rate-controlling membranes reported in previous publications included ethyl cellulose (Lewis, Pandey, Udupa, 2006), collagen and chitosan (Thacharodi, Rao, 1996), ethylene-vinyl acetate (EVA) (Shen et al., 2013) and acrylate polymers (Zhan et al., 2007a, b, c). Previous work in our lab has proven that acrylate polymers, as a new type of rate-controlling membranes, could control clonidine $\mathrm{HCl}$ solution release with zero order (Zhan et al., 2007a, b, c). But, such film-like acrylate polymers have not been applied in the production of patches to date.

The aim of this study was to develop a reservoirtype transdermal patch of ISDN with acrylate polymer as the rate-controlling membrane, which could keep drug release at a constant rate for at least $48 \mathrm{~h}$. The effects of chemical penetration enhancers, reservoir materials and rate-controlling membranes on the release behaviour of ISDN permeation across the transdermal patch were studied. Consequently, the in vitro release of ISDN from such a patch was studied in comparison to commercially available ISDN patches.

\section{MATERIAL AND METHODS}

\section{Material}

2-Hydroxy-3-phenoxypropylacrylate (marked A), 4-hydroxybutyl acrylate (marked B), diethyl maleate (marked C1), dibutyl maleate (marked C2) and 2-methyl2-nitropropyl methacrylate (marked C3) were purchased from Aldrich (USA). Benzoyl peroxide, ethyl cellulose (EC), polyethylene glycol 400 (PEG400), methylene chloride, ethanol absolute, oleic acid, urea, propylene glycol and polyvinyl alcohol 17-88 (PVA17-88) were purchased from National Medicine Corporation (CHN). Isosorbide dinitrate (ISDN) was purchased from Shanghai Yuanji Chemical Co., Ltd. Polyvinyl alcohol 05-88 (PVA05-88) was purchased from Shanghai Jin Wei Trading Co., Ltd. Polyvinyl pyrrolidone K90 (PVP K90) was presented by Boai New Kaiyuan Pharmaceutical Co., Ltd. Methanol was of HPLC grade. Frandol ${ }^{\circledR}$ tape was purchased from Yamanuchi Pharm (JP) (40 mg in $40 \mathrm{~cm}^{2}$ ). All other chemicals were of reagent grade and used as received.

\section{Fabrication of a reservoir-type transdermal patch of ISDN}

The structure of the transdermal patch consisted of five layers, namely, a temporary liner, an adhesive layer, a rate-controlling membrane, a reservoir and a backing (Figure 1). First, the adhesive solution was coated onto the temporary liner (3M, Scotchpak $\left.{ }^{\mathrm{TM}} 1022\right)$ and was allowed to dry completely. Then, a polyacrylate membrane, as a rate-controlling membrane, was pressed over the adhesive layer. Then, the reservoir layer was pressed onto the rate- 
controlling membrane. Last, the polyester film laminate (3M, Scotchpak ${ }^{\mathrm{TM}}$ 9732), as a backing layer, covered the reservoir. The temporary liner and the backing layer were then heat-sealed and cut to the appropriate sizes. The patch was stored in a sealed aluminium pouch to minimise the loss of solvent.

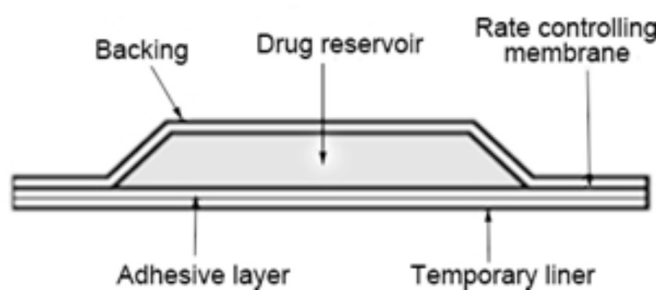

FIGURE 1- The construction of the ISDN transdermal patch.

\section{Preparation of the pressure-sensitive adhesives (PSAs)}

PSAs with ISDN (0.96 g PVP K90, $0.18 \mathrm{~g}$ PEG400, $0.06 \mathrm{~g}$ gelatin and $100 \mathrm{~mL}$ deionised water) were put into a three-necked boiling flask and stirred at $80{ }^{\circ} \mathrm{C}$ until the solid reagents dissolved completely; this was then refluxed for $2 \mathrm{~h} 120^{\circ} \mathrm{C}$ to decrease the strength and viscosity of the gelation solution. The solution was cooled before adding $0.06 \mathrm{~g}$ ISDN and stirring until the ISDN was homogeneously dispersed. The mixture was cast onto the temporary liner in $200 \mathrm{~cm}^{2}$ areas and dried at $60{ }^{\circ} \mathrm{C} ; 0.3 \mathrm{mg}$ of ISDN per $\mathrm{cm}^{2}$ was obtained in the PSAs.

The preparation process of PSA without ISDN was the same procedure, except no ISDN was added.

\section{Preparation of the rate-controlling membranes}

We used a previously reported method that had already been used in our lab to prepare three ratecontrolling membranes (Figure 2), that is, membrane M1 made of monomers A, B and C1 (Zhan et al., 2007a), membrane M2 made of monomers A, B and C2 (Zhan et

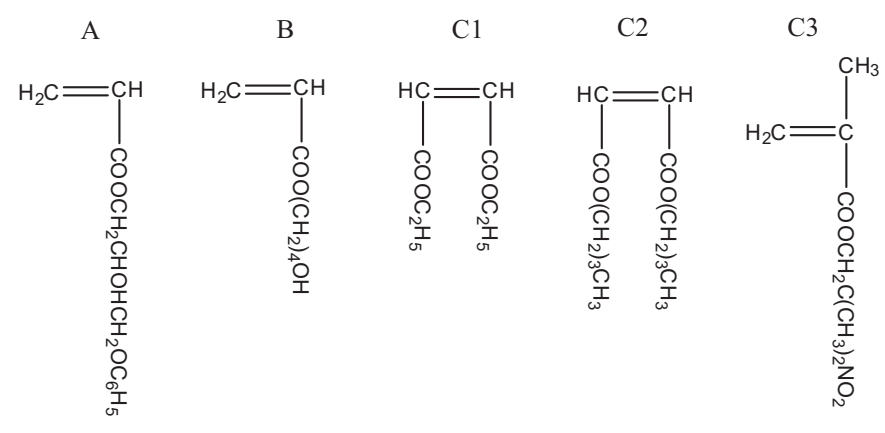

FIGURE 2 - The structure of acrylate monomers. al., 2007b), and membrane M3 made of monomers A, B and C3 (Zhan et al., 2007c). The ratio of the monomers in each membrane was 4:4:2(w/w/w). We used 3\% (w/w) benzoyl peroxide as the photo-initiator reagent. The mixture of monomers with the photo-initiator was treated under UV light in UV-curing equipment (Beijing Aishibo Machinery Electronic Equipment Centre, China). The thickness of all resultant membranes was $14 \mu \mathrm{m}$.

\section{Preparation of the drug reservoir}

ISDN in EC reservoir: $5.1 \mathrm{~g}$ of EC were completely dissolved in methylene chloride, and then $0.54 \mathrm{~g}$ of ISDN was added and dissolved. The mixed solution was casted onto a glass plate with $200 \mathrm{~cm}^{2}$ areas; the plate was then put in an air-conditioned chamber at room temperature for $24 \mathrm{~h}$ under $60-70 \%$ relative humidity in order to evaporate the methylene chloride, and a $2.7 \mathrm{mg}$ ISDN layer (per $\mathrm{cm}^{2}$ EC) was formed. The drug reservoir layer was separated carefully from the glass plate, and then pressed tightly on the rate-controlling membrane.

ISDN in PVA reservoir: $5.1 \mathrm{~g}$ of a PVA mixture (PVA0588/ PVA1788=1:2.5 $\mathrm{mol} / \mathrm{mol}$ ) was dissolved in water/ethanol $(1: 1 \mathrm{v} / \mathrm{v})$ solution, and then $0.54 \mathrm{~g}$ of ISDN was added and dissolved. The mixed solution was casted onto a glass plate with $200 \mathrm{~cm}^{2}$ areas, and then the plate was put in an oven (Hanzhou Huier Equipment Co., Ltd., China) at $65{ }^{\circ} \mathrm{C}$ for $24 \mathrm{~h}$ in order to evaporate $\mathrm{H}_{2} \mathrm{O}$ and ethanol, and a $2.7 \mathrm{mg}$ ISDN layer (per $\mathrm{cm}^{2} \mathrm{PVA}$ ) was formed. The drug reservoir layer was carefully separated from the glass plate and tightly attached to the ratecontrolling membrane.

\section{Preparation of the drug reservoir containing penetration enhancer}

The preparation of the drug reservoir with a penetration enhancer followed the same procedure as the preparation of the PVA reservoir layer. When ISDN was dissolved in PVA solution, 15\% (w/w) oleic acid, 15\% $(\mathrm{w} / \mathrm{w})$ 1,2-propylene glycol and 5\% (w/w) urea were used as penetration enhancers, which were added into the PVA reservoir layer, stirred and homogeneously dispersed in the reservoir.

\section{Characterisation of optimised formulation}

\section{Thickness}

The patch thickness was measured using a digital meter (Shanghai Measuring and Cutting Tools Factory, China) at five different places. The average and standard 
deviation of five readings were calculated for three batches of the optimised formulation with an area of $1 \mathrm{~cm}^{2}$.

\section{Weight}

Three different patches from three batches, each with an area of $1 \mathrm{~cm}^{2}$, were weighed individually, and the average weight and standard deviation was calculated.

\section{Drug content}

Three individual patches from three batches, each with an area of $1 \mathrm{~cm}^{2}$, were cut into small pieces and dissolved in $100 \mathrm{~mL}$ of methanol/water solution (54:46 $\mathrm{v} / \mathrm{v})$. The solution was filtered, diluted suitably and measured by HPLC.

\section{Skin for permeation studies}

Hairless rat skin was used to evaluate the effects of penetration enhancers on the permeation and to evaluate the permeation of ISDN release from the optimised developed patch. The skin was isolated from hairless rats (male, 8-10 weeks old and 350-400 $\mathrm{g}$ in weight) that were obtained from Slac Lab. Animal (Shanghai, China). All studies were performed as per the protocol approved by the Institutional Animal Care and Use Committee (IACUC) at Shanghai Jiaotong University. Hairless rats were euthanised by carbon dioxide asphyxiation prior to the permeation experiment and its abdominal skin was carefully excised using scissors and forceps. The underlying subcutaneous fat was removed from the excised skin and the thus-obtained abdominal skin (ca. $1 \mathrm{~mm}$ thick) was used for permeation experiments.

\section{Permeation studies}

Permeation experiments were carried out to evaluate the rate-controlling membrane, the drug reservoirs, the penetration enhancers and the integral developed patch. The tested component was cut into appropriate sizes and mounted on a modified Franz diffusion assembly ( $\mathrm{Ng}$ et al., 2010) produced at Huanghai Medicine \& Drug Testing Instruments (China). When the tested component was the integral developed patch, the temporary line should be removed, and the dermis side of the skin faced the receptor compartment. The effective diffusion area was $0.785 \mathrm{~cm}^{2}$. The receptor compartment was filled with $25.0 \pm 0.1 \mathrm{~mL}$ of PEG400 and normal saline in the volume ratio of $4: 6$, and the sink conditions were maintained during the permeation experiment. The receptor medium was maintained at $37.0 \pm 0.1^{\circ} \mathrm{C}$ and stirred constantly at $200 \pm 2 \mathrm{rpm}$. At pre-determined time intervals $0.5,1.5,3,4.5,6.5,8.5$, $10.5,12$ and $24 \mathrm{~h}, 200 \mu \mathrm{L}$ of the receptor solution was taken out and replaced with an equal volume of fresh receptor medium. The samples were analysed by HPLC.

\section{HPLC analysis of ISDN}

The HPLC system (Waters, USA) consisted of a 1525 binary pump, a 717 plus auto-sampler and a 2487 dual-wavelength UV absorbance detector. Data acquisition and processing were dealt with by Waters Empower professional software. The mobile phase was a mixture of methanol and water in the volume ratio of $54: 46$. The mobile phase was filtered through a $0.45 \mathrm{~mm}$ porosity filter and degassed. The liquid chromatograph was equipped with a $80 \AA, 5 \mu \mathrm{m}, 4.6 \mathrm{~mm} \times 250 \mathrm{~mm} \mathrm{C} 18$ column (Agilent Zorbax Extend) with a flow rate of $1 \mathrm{~mL} / \mathrm{min}$. The volume of each injected sample was $20 \mu \mathrm{L}$, the wavelength of the UV detector was set at $220 \mathrm{~nm}$, and the run time was $15 \mathrm{~min}$ (USP 32, 2009).

\section{Validation studies of the HPLC method}

\section{Linearity and range}

A stock solution of ISDN (1 mg/mL) was prepared in the mobile phase. Seven standard solutions (1 to $100 \mu \mathrm{g} / \mathrm{mL}$ ) were diluted from this stock solution using the mobile phase for the assessment of linearity. The peak areas for ISDN $(n=5)$ versus concentrations were plotted and fitted to be linear over the entire concentration range.

\section{Accuracy}

The accuracy was determined by recovery studies. The samples were analysed at three concentrations of 5, 25 and $100 \mu \mathrm{g} / \mathrm{mL}$ by the proposed method. The experiments were conducted in triplicate.

\section{Precision}

The intra-day variability was checked at three time points on the same day, and the inter-day variability was checked on three consecutive days. The samples were analysed at three concentrations of 5, 25 and $100 \mu \mathrm{g} / \mathrm{mL}$ by the proposed method. The results were expressed as the percent relative standard deviation (\% RSD) of concentration.

\section{Specificity}

A set of sample solutions were prepared to ascertain the specificity of the method. The blank solution was the mobile phase, the standard solution contained $50 \mu \mathrm{g} / \mathrm{mL}$ ISDN dissolved in the mobile phase, the drug substance solution was $50 \mu \mathrm{g} / \mathrm{mL}$ ISDN dissolved in the receptor medium (PEG400: normal saline $=4: 6 \mathrm{v} / \mathrm{v}$ ), placebo 
1 solution contained PSAs $(50 \mu \mathrm{g} / \mathrm{mL}$ PVP K90 and $50 \mu \mathrm{g} / \mathrm{mL}$ gelation dissolved in the receptor medium and then filtered), placebo 2 solution contained penetration enhancers $(50 \mu \mathrm{g} / \mathrm{mL}$ oleic acid, $50 \mu \mathrm{g} / \mathrm{mL}$ 1,2-propylene glycol and $50 \mu \mathrm{g} / \mathrm{mL}$ urea dissolved in the receptor medium and then filtered) and placebo 3 was for the drug reservoir $(50 \mu \mathrm{g} / \mathrm{mL}$ EC, $50 \mu \mathrm{g} / \mathrm{mL}$ PVA0588 and $50 \mu \mathrm{g} / \mathrm{mL}$ PVA 1788 dissolved in the receptor medium and then filtered).

\section{Detection and quantitation limits}

The LOD (limit of detection) and LOQ (limit of quantitation) were defined as the concentrations that yielded a measured peak with a $\mathrm{S} / \mathrm{N}$ (signal-to-noise ratio) of 3 and 10, respectively.

\section{Test of sink conditions}

Assuring the sink conditions in the in vitro release experiment is very important. According to the requirements of the sink conditions, the volume of the receptor medium was generally greater than 5-10 times that of the saturation point of ISDN in this medium. Thus, the saturated solubility of ISDN in the receptor medium needed to be quantified. ISDN was added to the flask with $25.0 \mathrm{~mL}$ of the receptor medium and sonicated for $24 \mathrm{~h}$ at $20^{\circ} \mathrm{C}$ until no more solid dissolved. The saturated solution was filtered and then measured by HPLC.

\section{Data analysis}

The cumulative amount of ISDN was calculated as follows:

$$
Q=\frac{C_{n} V+\sum_{i=1}^{i=n-1} C_{i} V_{i}}{A}
$$

where $Q$ is the cumulative amount of the drug $\left(\mu \mathrm{g} / \mathrm{cm}^{2}\right)$, $V$ is the receptor solution volume $(\mathrm{mL}), V_{i}$ is the sample volume (mL), $C_{n}$ and $C_{i}$ are the drug concentrations in the receptor cells and the concentration of the extraction samples $(\mu \mathrm{g} / \mathrm{mL})$, respectively, and $A$ is the transporting area $\left(\mathrm{cm}^{2}\right)$.

The cumulative drug amount $\left(Q_{t}, \mu \mathrm{g} / \mathrm{cm}^{2}\right)$ was plotted versus time $(T, \mathrm{~h})$. The slope of the linear portion of the plot was presented as the permeation rate $\left(J_{s s}\right.$, $\mu \mathrm{g} / \mathrm{cm} / \mathrm{h})$. The intercept on the $x$-axis was taken as the lag time $\left(T_{L}, \mathrm{~h}\right)$. All of the release experiments were repeated three times from independent batches, and mean values of the permeation rates with standard deviations were calculated. Student's $t$-test and analysis of variance (ANOVA) were used to statistically determine significant differences. The $p$ value used in this study was 0.05 .

\section{RESULTS AND DISCUSSION}

\section{Method validation of HPLC}

\section{Linearity and range}

The calibration curve for ISDN obtained from the developed HPLC method was displayed in Figure 3. As shown, the peak areas of the drugs were obtained to be strictly linear in the concentration range of 1 to $100 \mu \mathrm{g} / \mathrm{mL}$; the correlation coefficient value was 0.9999 .

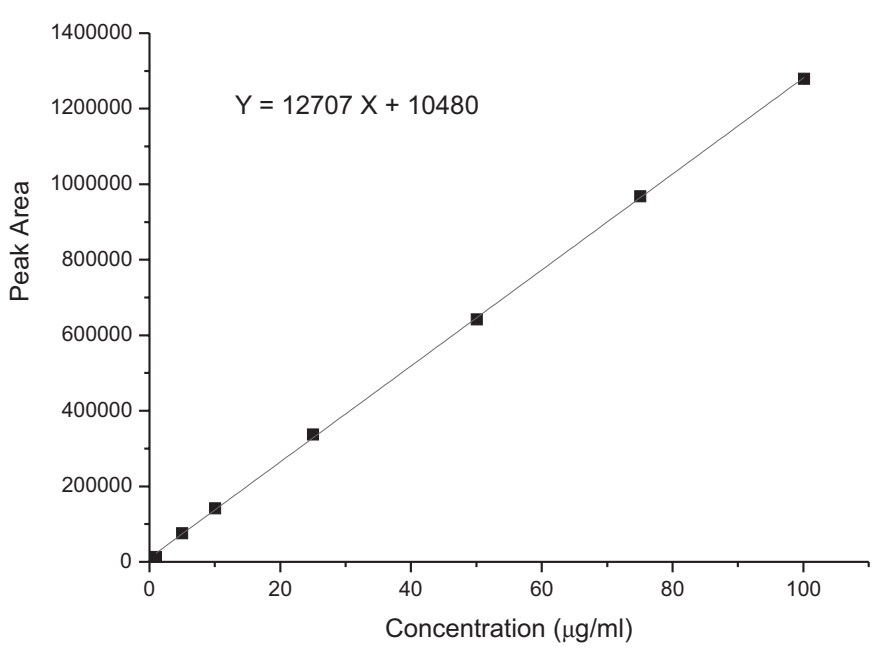

FIGURE 3 - Calibration curve for ISDN from the HPLC method.

\section{Accuracy}

The percentage recoveries of the three concentrations from low to high were found to be $102.07 \pm 0.63$, $102.75 \pm 0.21$ and $99.78 \pm 0.32 \%$, respectively, which confirms that the method was accurate.

\section{Precision}

The \% RSD of the developed intra-day HPLC method was $0.44 \pm 0.28$, and the \% RSD of inter-day method was $0.52 \pm 0.22$, which suggests the excellent precision of the developed HPLC method.

\section{Detection and quantitation limits}

The LOD and LOQ values were found to be 100 and $350 \mathrm{ng} / \mathrm{mL}$, respectively.

\section{Specificity}

The method specificity was assessed by comparing the chromatograms obtained from the sample solutions 


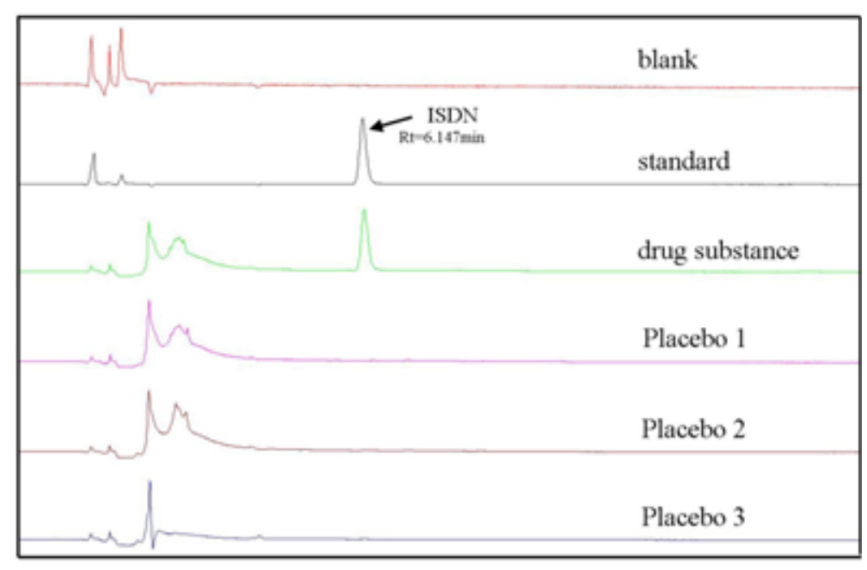

FIGURE 4 -Chromatograph from HPLC obtained from different sample solutions.

(Figure 4); the retention time of ISDN observed from the HPLC was $6.147 \mathrm{~min}$.

\section{Evaluation of sink conditions}

The solubility of ISDN in the PEG400/normal saline solution $(4: 6 \mathrm{v} / \mathrm{v})$ at $20^{\circ} \mathrm{C}$ was $1.85 \pm 0.03 \mathrm{mg} / \mathrm{mL}(n=3)$. The solubility of ISDN in water at $20^{\circ} \mathrm{C}$ was $1.45 \pm 0.01 \mathrm{mg} / \mathrm{mL}$ $(n=3)$. The solubility of ISDN in PEG400/normal saline solution increased slightly compared to its solubility in water. The highest drug content in our research was $5 \mathrm{mg}$ (the concentration in donor compartment: $5 \mathrm{mg} / \mathrm{mL}$, volume: $1 \mathrm{~mL}$ ), and the receptor media volume was $25 \mathrm{~mL}$; the concentration was $0.2 \mathrm{mg} / \mathrm{mL}$ if $5 \mathrm{mg}$ of ISDN was completely dissolved in $25 \mathrm{~mL}$ of media. Thus, the receptor media volume was nine times greater than the saturation point and the sink conditions were achieved during the permeation experiment. In fact, other researchers also used water as the receptor media for the purpose of simulating a human physiological environment (Zhao et al., 2007).

\section{Effect of the rate-controlling membrane on the permeation}

To screen a suitable rate-controlling membrane, different concentrations of ISDN in 1,2-propylene glycol solution $(1.0,2.0,3.0$, and $5.0 \mathrm{mg} / \mathrm{mL})$ were used as donor solutions in the modified Franz cells with a volume of $1 \mathrm{~mL}$. The release behaviours of ISDN across different rate-controlling membranes were studied over $24 \mathrm{~h}$. It was found that the rate-controlling membrane marked M1 showed the highest value of permeation rates under the same drug-donor concentration, as shown in Figure 5. This result could be explained by the pore sizes of membrane M1, which was fabricated randomly by polymer chains. As polyacrylates are non-degradable polymers, they are controlled drug molecules across the pores in the membrane instead of degradation, erosion or dissolution of the polymer. The shorter side chain of monomer $\mathrm{C} 1$ would occupy the pore's inner space less compared with $\mathrm{C} 2$ and $\mathrm{C} 3$, as a result of the drug molecules release across the membrane M1 more easily. Membrane M1 also showed higher permeation rates compared to M2 and M3 when the tested drug was clonidine $\mathrm{HCl}$ (Zhan et al., 2007a,b,c).

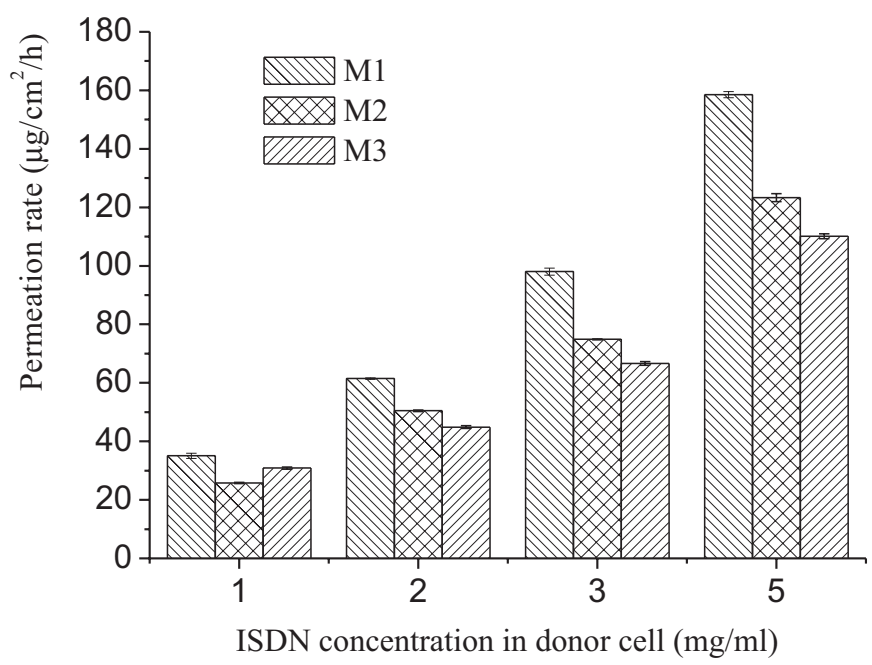

FIGURE 5 - The permeation of ISDN through different ratecontrolling membranes.

\section{Effect of the drug reservoir on the permeation}

Two types of drug reservoir, EC and PVA, were designed. The permeation of ISDN from the drug reservoir across rate-controlling membrane M1 was studied. Table I

TABLE I - The permeation of ISDN releasing from the drug reservoir across M1

\begin{tabular}{ccccccc}
\hline Formulation & Reservoir & $\boldsymbol{J}_{\boldsymbol{s s}}\left(\boldsymbol{\mu g} / \mathbf{c m}^{2} / \mathbf{h}\right)$ & $\begin{array}{c}\text { Cumulative } \\
\text { amount of } \\
\text { release at } \mathbf{2 4} \mathbf{h} \\
\mathbf{( \mu g )}\end{array}$ & $\begin{array}{c}\text { Correlation } \\
\text { factor }\left(\boldsymbol{r}^{2}\right)\end{array}$ & $\boldsymbol{T}_{\boldsymbol{L}} \mathbf{( h )}$ & $\begin{array}{c}\text { Cumulative } \\
\text { ratio of release } \\
\text { at 24 h } \mathbf{( \% )}\end{array}$ \\
\hline $\mathrm{F} 1$ & $\mathrm{EC}$ & $1.7 \pm 0.1$ & $30.7 \pm 1.1$ & 0.9967 & 8.1 & $1.3 \pm 0.03$ \\
$\mathrm{~F} 2$ & $\mathrm{PVA}$ & $43.2 \pm 1.8$ & $957.2 \pm 54.3$ & 0.9817 & - & $40.1 \pm 0.8$ \\
\hline
\end{tabular}


shows that PVA had a better permeation compared with EC, which increased the permeation rate 25.4 fold, a 31.1 -fold cumulative release after $24 \mathrm{~h}$, and a 30.8 -fold cumulative ratio of release at $24 \mathrm{~h}$. Moreover, ISDN releasing from PVA were not observed in the lag time, but EC had serious lag time of $8.1 \mathrm{~h}$. So, the PVA was chosen to perform latter experiment.

\section{Effect of the penetration enhancers on the permeation}

To screen the penetration enhancers, three penetrations covering a broad range of lipophilicity values ( $\log P$ values of penetrations amounted to $-2.11,-0.92$ and 7.7 for urea, propylene glycol and oleic acid, respectively) (Table II) (Yangali-Quintanilla et al., 2009) were chosen to investigate the impact of the partitioning characteristic of penetrations on the permeation. The weight ratio of the penetration enhancers were reported in a previously published paper (Halina; Krzysztof; Stanislaw, 2000; Chen et al., 1992). The release behavior of ISDN in the PVA reservoir with the penetration enhancer transporting across the M1 was evaluated (Table III). It was found that there was no significant promotion on the permeation rates among the groups of drug reservoirs with or without penetration enhancers $(p>0.05)$ (Table IV).

TABLE II - Physicochemical properties of penetration enhancers

\begin{tabular}{lcc}
\hline $\begin{array}{l}\text { Penetration } \\
\text { enhancers }\end{array}$ & $\begin{array}{c}\text { Molar mass } \\
(\mathrm{g} / \mathbf{m o l})\end{array}$ & $\log \boldsymbol{P}^{*}$ \\
\hline Oleic acid & 282.46 & 7.7 \\
Propylene glycol & 76.05 & -0.92 \\
Urea & 60.06 & -2.11 \\
\hline
\end{tabular}

* Experimental data

Although the penetration enhancers had no effects when the drug transported across the rate-controlling membrane, M1, it was well known that the penetration enhancers had serious effects on the skin in general. To further illustrate how the penetration enhancers affected the permeation rates, the release behaviours of ISDN in the formulation groups F2, F3, F4 and F5 transporting across the rats' ex-vivo skin were studied. It was found that formulation F5, of which urea was the penetration enhancer, had a higher permeation rate, cumulative amount of release and cumulative ratio of release compared to oleic acid and propylene glycol $(p<0.05)$ (Figure 6). The fastest rate of permeation in the case of urea was explained by it having the lowest molecular weight when compared to the more lipophilic penetrations (Table II), as well as by its permeation-enhancing potential for the hydrophilic drugs because the value of $\log P$ of ISDN was 0.95 , as calculated using Advanced Chemistry Development (ACD/Labs) Software V 11.02 (Ochalek et al., 2012).

Actually, the excised animal skin could not represent the real permeation of drugs transporting through human skin. But, the animal skin is frequently used as a replacement for human skin, because the human skin is difficult to acquire under ethical principles. Schmook et al (2001) compared the penetration properties of human skin with animal (pig and rat) skin for four topical dermatological drugs (salicylic acid, hydrocortisone, clotrimazole and terbinafine) with widely varying polarity. The results revealed that the order of permeation rates was rat $>$ pig $>$ human (terbinafine), rat $>$ pig human (clotrimazole), rat $>$ human $>$ pig (hydrocortisone), rat $>$ human $>$ pig (salicylic acid). Thus, we could surmise the permeation rates of the drug transporting through the human skin would be less than the values of rat skin.

\section{Effect of the pressure sensitive adhesive on the permeation}

When PVA was used as the drug reservoir, urea was used as the penetration enhancer and M1 was used as the rate-controlling membrane, the in vitro release behaviour of the PSA through the rats' ex-vivo skin was studied. Comparing the values of the permeation rates of formulation groups F5 and F6, it was found that the value of $J_{s s}$ showed a significant decrease when the PSA was

TABLE III - Permeation of ISDN in PVA reservoir with different penetration enhancers transporting through the M1

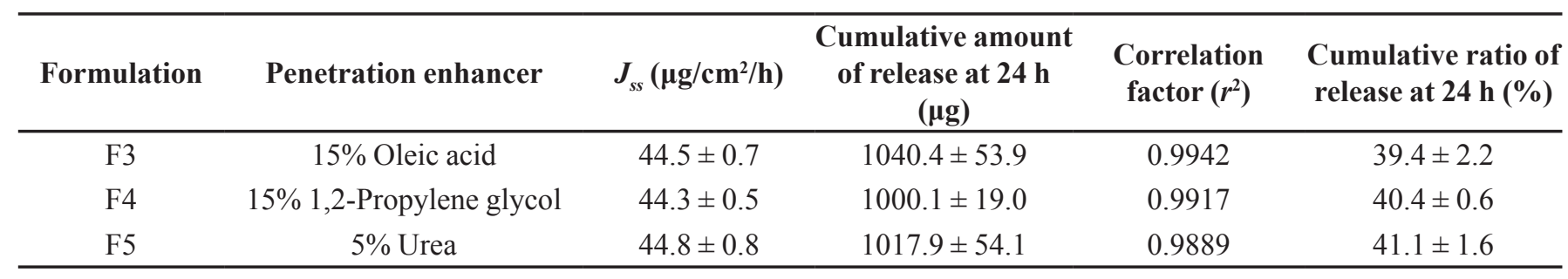


TABLE IV - Comparison of the $p$ values from the permeation rates in four formulation groups

\begin{tabular}{ccc}
\hline Comparison formulation groups & $\boldsymbol{p}$ value \\
\hline F2 & F3 & 0.33 \\
& F4 & 0.38 \\
F3 & F5 & 0.24 \\
& F4 & 0.75 \\
F4 & F5 & 0.62 \\
\hline
\end{tabular}

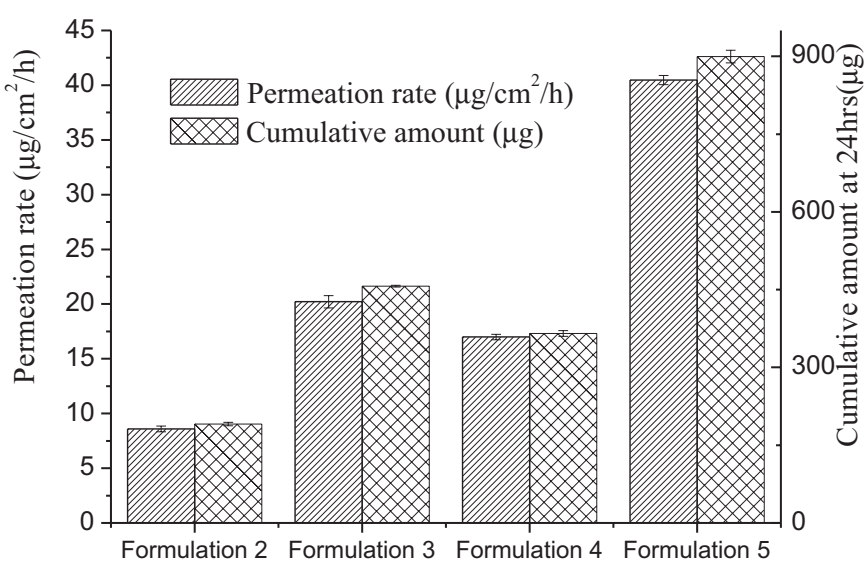

FIGURE 6 - In vitro release of ISDN in four formulations with different penetration enhancers across through the rats' ex-vivo skin.

used in the formulation $(p<0.05)$. To increase the value of $J_{s s}, 5 \%(\mathrm{w} / \mathrm{w})$ ISDN was added into the PSA, as shown in formulation $\mathrm{F} 7$, and promotion effects of permeation were observed in formulation F7 compared with formulation F6 $(p<0.05)$ (Table V).

\section{Pharmaceutical equivalent evaluation}

Commercially available Frandol@ Tape was used a controlling group. Comparing in vitro releasing behavior of formulation group F7 and Frandol® Tape, it was found that both groups could control drug release at a sustained rate for up to $48 \mathrm{~h}$. There were no significant differences in the permeation rates between formulation F7 and the controlling group $(p>0.05)$. The cumulative release ratio at $48 \mathrm{~h}$ of the developed patch was only $34.9 \%$, but up to $89.8 \%$ in the Frandol ${ }^{\circledR}$ Tape (Figure 7 ), which meant that the developed patch would release at a constant rate for a longer time than the controlling group. The reason for the significant difference in cumulative release ratio of the two patches was that the amount of ISDN in the developed patch was up to $3 \mathrm{mg} / \mathrm{cm}^{2}$ but in the Frandol ${ }^{\circledR}$ Tape it was only $1 \mathrm{mg} / \mathrm{cm}^{2}$. In comparison with Frandol ${ }^{\circledR}$ Tape, which was a single-layer adhesive-type patch, the developed reservoirtype patch showed advantages, whereby the permeation rates were controlled by the rate-controlling membrane and the drug-release time was decided by the amount of drugs in the reservoir layer. Thus, it was easy to tune the release rate and release time to achieve the prediction.

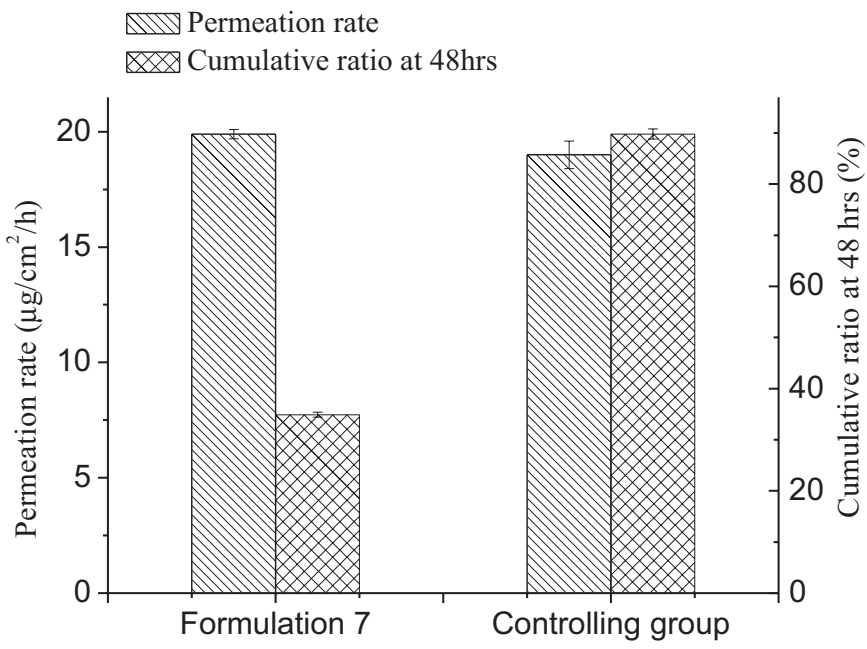

FIGURE 7 - Comparison release of the developed patch with the controlling group.

\section{Physical evaluation of optimised patches}

The optimised formulation, F7, with an area of $1 \mathrm{~cm}^{2}$

TABLE V - In vitro release of formulations with different pressure sensitive adhesives

\begin{tabular}{|c|c|c|c|c|c|}
\hline Formulation & PSA & $\underset{\left(\mu \mathrm{g} / \mathbf{c m}^{2} / \mathbf{h}\right)}{J_{s s}}$ & $\begin{array}{c}\text { Cumulative amount } \\
\text { of release at } 48 \mathrm{~h} \\
(\mu \mathrm{g})\end{array}$ & $\begin{array}{c}\text { Correlation factor } \\
\left(r^{2}\right)\end{array}$ & $\begin{array}{l}\text { Cumulative ratio of } \\
\text { release at } 48 \mathrm{~h}(\%)\end{array}$ \\
\hline F5 & - & $24.4 \pm 0.1$ & $1045.7 \pm 19.5$ & 0.9974 & $42.8 \pm 1.1$ \\
\hline F6 & PSA without ISDN & $16.7 \pm 0.7$ & $713.5 \pm 35.4$ & 0.9937 & $28.9 \pm 1.2$ \\
\hline F7 & PSA with ISDN & $19.9 \pm 0.2$ & $861.4 \pm 3.3$ & 0.9972 & $34.9 \pm 0.5$ \\
\hline \multicolumn{2}{|c|}{ Controlling group } & $19.0 \pm 0.6$ & $852.9 \pm 9.6$ & 0.9945 & $89.8 \pm 1.0$ \\
\hline
\end{tabular}


was tested for various physical parameters. The thickness of formulation F7 was found to be $256.4 \pm 11.8 \mu \mathrm{m}$. The weight of formulation F7 was $43.7 \pm 1.3 \mathrm{mg}$. The drug content in formulation F7 was $2954.7 \pm 20.3 \mathrm{mg}$. Compared to the calculated drug content of $3 \mathrm{mg} / \mathrm{cm}^{2}$, the percent loss of drug in the preparation process was below $2 \%$. The results indicated that the reservoir-type transdermal patch of ISDN developed in this study possessed uniform thickness, weight and drug content.

\section{CONCLUSION}

A reservoir-type transdermal patch of ISDN was prepared in this paper. The developed patch was fabricated by a temporary liner, an adhesive layer, a rate-controlling membrane, a reservoir and a backing. In the developed patch, the optimised drug reservoir included $75 \%$ PVA, $10 \%$ ISDN and $5 \%$ urea; the optimised rate-controlling membrane was synthesised by 2-hydroxy-3-phenoxypropylacrylate, 4-hydroxybutyl acrylate and diethyl maleate; the optimised PSA was 5\% ISDN dispersed in the mixture of PVP K90, PEG400 and gelatine. Compared with the commercial patch, the developed patch presented a longer release time at a sustained release rate and would promote patient satisfaction. Such a reservoir-type transdermal patch had more advantages over the adhesive-type patch, including sustained release rate, owing to the rate-controlling membrane, and a higher loading-drug amount, owing to the separated drug reservoir layer. Thus, it was easy to tune release rate and release time to achieve the prediction.

\section{ACKNOWLEDGEMENTS}

This work was supported by the national significant and special project of new created drugs (No. 2010ZX09401-404).

\section{REFERENCES}

CHEN, G. L.; SHI, X. Z.; ZHANG, Z. H.; ZHANG, F. Q.; WANG, C. M.; LI, Y. C. Study on percutaneous therapeutic system of isosorbide dinitrate effect of penetration enhancers on in vitro permeability through rat skin. Chin. J. Pharm., v.23, n.10, p.449-451, 1992.

FUNG, H.L. Nitrate formulations and drug delivery systemsan overview. Z. Kardiol. v. 74, p.4-9, 1985. Supplement 4.
HALINA, G.; KRZYSZTOF, C.; STANISLAW, J. Effect of penetration enhancers on isosorbide dinitrate penetration through rat skin from a transdermal therapeutic system. Int. J. Pharm., v.199, n.1, p.1-6, 2000.

JOHNSON, K.I.; GLADIGAU, v.; SCHNELLE, K. Relationship between the pharmacodynamics and pharmacokinetics of two oral sustained-release formulations of isosorbide dinitrate in normal man. Arzneim.-Forsch., v.31, p.10261029, 1981.

LEWIS, S.; PANDEY, S.; UDUPA, n.Design and evaluation of matrix type and membrane controlled transdermal delivery systems of nicotine suitable for use in smoking cessation. Indian. J. Pharm. Sci., v.68, n.2, p.179-184, 2006.

NG, S.W.; ROUSE, J.J.; SANDERSON, F.D.; MEIDAN, v.; ECCLESTON, G.M. Validation of a static Franz diffusion cell system for in vitro permeation studies. Aaps Pharmscitech, v. 11, n.3, p.1432-1441, 2010.

OCHALEK, M.; PODHAISKY, H.; RUETTINGER, H.H.; NEUBERT, R.H.H.; WOHLRAB, J. SC lipid model membranes designed for studying impact of ceramide species on drug diffusion and permeation, Part III: Influence of penetration enhancer on diffusion and permeation of model drugs. Int. J. Pharm., v.436, n.1-2, p.206-213, 2012.

PRAUSNITZ, M.R.; LANGER, R. Transdermal drug delivery. Nat. Biotechnol., v.26, n.11, p.1261-1268, 2008.

SCHMOOK, F.P. ; MEINGASSNER, J.G.; BILLICH, A. Comparison of human skin or epidermis models with human and animal skin in in-vitro percutaneous absorption. Int. J. Pharm., v.215, n.1-2, p.51-56, 2001.

SHEN, T.; XU, H.; WENG, W.; ZHANG, J. Development of a reservoir-type transdermal delivery system containing eucalyptus oil for tetramethylpyrazine. Drug Deliv., v.20, n.1, p.19-24, 2013.

SUBEDI, R.K.; OH,S. Y.; CHUN, M.K.; CHOI, H.K. Recent advances in transdermal drug delivery. Arch. Pharm. Res., v.33, n.3, p.339-351, 2010.

TAN, H.S.; PFISTER, W.R. Pressure-sensitive adhesives for transdermal drug delivery systems. Pharm. Sci. Technol. Today, v.2, n.2, p.60-69, 1999. 
TAYLOR, T.; CHASSEAUD, L.F.; MAJOR, R.M.; LEAF, F.C.; BONN, R.; DARRAGH, A.; LAMBE, R.F. Bioequivalence of a sustained-release isosorbide dinitrate formulation at steady-state. Biopharm. Drug Dispos., v.6, n.2, p.119-129, 1985 .

THACHARODI, D.; RAO, K.P. Rate-controlling biopolymer membranes as transdermal delivery systems for nifedipine: development and in vitro evaluations. Biomaterials, v.17, n.13, p.1307-1311, 1996.

UNITED STATES PHARMACOPEIAL CONVENTION. USP. USP 32 NF 27: United States Pharmacopeia [and] National Formulary. Rockville: United States Pharmacopeial Convention, 2009. v. 2, p.2712-2718.

YANGALI-QUINTANILLA, v.; VERLIEFDE, A.; KIM. T.U.; SADMANI, A.; KENNEDY, M.; AMY, G. Artificial neural network modes based on QSAR for predicting rejection of neutral organic compounds by polyamide nanofiltration and reverse osmosis membranes. J. Membrane Sci., v.342, n.1-2, p.251-262, 2009.

ZHAN, X.P. ; CHEN, S. J.; TANG, G.C.; MAO, Z.M.A new poly (2-hydroxy-3-phenoxypropylacrylate, 4-hydroxybutyl acrylate, diethyl maleate) membrane controlled clonidine linear release in the transdermal drug delivery system. Eur. Polym. J., v.43, n.4, p.1588-1594, 2007a.
ZHAN, X.P. ; CHEN, S.J.; TANG, G.C.; MAO, Z.M. Poly (2-hydroxy-3-phenoxypropylacrylate, 4-hydroxybutyl acrylate, dibutyl maleate) membrane controlled clonidine zero-order release. Eur. J. Pharm. Biopharm., v.66, n.3, p.429-434, $2007 b$.

ZHAN, X.P. ; CHEN, S.J.; TANG, G.C.; MAO, Z.M. TWO new types of copolymer membranes controlling clonidine zero-order release. J. Appl. Polym. Sci., v.106, n.5, p.3016$3022,2007 \mathrm{c}$.

ZHAO, J.H.; FU, J.H.; WANG, S.M.; SU, C.H.; SHAN, Y.; KONG, S.J.; WANG, Y.; LU, W.L.; ZHANG, H.; ZHANG, S.; LI, L.; ZHANG, E.H.; WANG, L.; PEI, Q. L.; WANG, J.C.; ZHANG, X.; ZHANG,Q. A novel transdermal patch incorporating isosorbide dinitrate with bisoprolol: in vitro and in vivo characterization. Int. J. Pharm., v.337, n.1-2, p.88-101, 2007.

Received for publication on $27^{\text {th }}$ March 2014 Accepted for publication on $17^{\text {th }}$ November 2014 